\title{
Study of the English Autonomous Learning Situation of College Freshmen in the "Internet Plus" Era
}

\author{
Ying Wang \\ Foreign Language Department, \\ Beijing Institute of Petrolchemical Technology, \\ Beijing, China \\ Chao Wang \\ Foreign Language Department, \\ Beijing Institute of Petrolchemical Technology, \\ Beijing, China
}

\begin{abstract}
Combining "the Internet plus" technology with education makes it possible and convenient for learning to happen beyond the restraints of time and place. Following this new trend of autonomous learning, learners have obtained easier access to the learning resources they need. Freshmen are clearly an indispensable group who benefit from it. Based on the theory of multiple intelligences and constructivist learning theory, this thesis aims to discover the current status of freshmen's autonomous learning in the internet plus era through questionnaires and interviews, explore the impact of learning tools and learning environments supported by internet plus technology on students' autonomous learning ability and effectiveness, and provide some corresponding advice for college English learning and teaching practice. A questionnaire survey followed by a face-to-face interview is employed in this thesis. The researcher randomly selected 460 freshmen with an English proficiency of level B (the intermediate level based on the Entrance Level Test hosted by BIPT) as subjects, issued relevant questionnaires online, and analyzed the final data via SPSS 20. Results show that freshmen at BIPT do have the awareness of autonomous learning with the help of various platforms online and apps on smart phones, but they have problems in making a long-term study plan, and following the plan regularly. They do have the motivation to improve their English competency through autonomous learning in the "Internet-plus" environment, but they have difficulty in information processing and resources acquisition. There is a correlation between college freshmen's autonomous learning ability and their English academic achievements. Freshmen with better abilities of autonomous learning tend to get higher scores in the English test. It is strongly suggested that students should be more self-disciplined in terms of selfplanning and self-supervising. In order to guarantee the effectiveness of autonomous learning, it is necessary for teachers to provide specific guidance, such as helping students make feasible study plans and regularly checking their implementation of the plans. Due to the limitation of time and resources, the design of the questionnaire only focuses on certain aspects of autonomous learning, and the quantity of the sampling is not large enough. The author hopes that more researches would be done to further explore the nature of autonomous learning in the "Internet plus" era and make it a booster for education and self-development.
\end{abstract}

Key words: internet plus technology, autonomous learning, English, freshmen

\section{BACKGROUND OF THE STUDY}

Since 1980s, studies concerning autonomous learning have attracted many scholars' attention. They became increasingly interested in learners' abilities to take charge of their own learning. 
It seems that such a self-control process is more helpful for learners to achieve their learning goals than the traditional classroom learning.

In the era of information explosion, the rapid development of information technology has brought great convenience to teaching and learning, which contributes to a combination of education and information technology. Thanks to the emergence and popularity of mobile network, a large variety of mobile learning apps and on-line learning platforms, such as Lanmoyun APP, Fif APP, and MOOC, have constitute a significant source of teaching and learning.

Autonomous learning in the "internet plus" era is undoubtedly a fresh product of the times and yields more possibilities for learners to achieve their personal goals. The diversification of educational methods create more access for students to construct knowledge in an autonomous way whenever and wherever they are, which is an effective supplement for the traditional learning on schedules in classrooms. The "internet plus" education environment provides numerous information and materials to learners, which can meet the particular needs of individuals. However, this kind of education constitutes more and more demand for the autonomous learning ability of learners, especially the freshmen who are keen on skillful in novel technology, have a lot of free time, and are curious about new things. The mobile devices and public free Wi-Fi make English learning more convenient and autonomous learning easier.

Many scholars all over the world began to focus on the internet-based autonomous learning, aiming to explore the correlation between academic performance and the autonomous learning ability. They find out that college students have problems in their motivation, selfadjustment, self-monitoring, self-evaluation, and selection and utilization of resources (Jin Ruixia, 2017; Liu Shujun, 2014). These studies also put forward solutions. There are also some studies emphasizing freshmen's role conversion and target location, and learning motivation and interest (Liu Chunyu\& Wang Kefeng, 2007; Wang Lei, 2014; Zhang Shujun, 2018). But few of them have an eye on the autonomous learning of freshmen, a special group of learners at the significant stage of their school life, whose autonomous learning in the internet plus era seems to be exceptionally vital and meaningful.

The first year in college, the transition to real college life, is an important stage for students. At this stage, freshmen are affected by a great deal of information from the society. Time for learning becomes more flexible than before, and extracurricular activities are more abundant, which requires them to have better autonomous learning ability to efficiently distribute time and energy to learning. In the Internet plus era, the ability and effectiveness of freshmen's autonomous learning are significant to be improved.

So this study tries to take the freshmen at Beijing Institute of Petro-chemical Technology (BIPT) as subjects. All of them are non-English majors with an English proficiency of level B (the intermediate level based on the Entrance Level Test hosted by BIPT). Based on the theory of multiple intelligences and constructivist learning theory, this study is expected to survey the status of English autonomous learning through questionnaires and interviews, explore the impact of learning tools and learning environments supported by internet plus technology on students' autonomous learning ability and effectiveness, and provide some reference for college English learning and teaching. The following three questions are raised: What is the current status of freshmen's English autonomous learning in the internet plus era? Is college freshmen's autonomous learning ability correlated with their English academic achievements in the internet plus era? How to improve college freshmen's autonomous learning efficiency in "the Internet Plus" era? 


\section{THEORETICAL FOUNDATION AND LITERATURE REVIEW}

Based on the previous studies, the concepts of the Internet plus education, autonomous learning, and autonomous learning in the Internet plus era are introduced in detail. The relevant definitions and characteristics are proposed.

\section{The Internet plus education}

Aiming to identify the internet plus education, it is necessary to firstly interpret the concept of the internet plus. Internet plus (internet+) was proposed by Chinese Prime Minister Li Keqiang in his Government Work Report on March 5, 2015. It applies the Internet and other information technologies to traditional industries, which can connect various internets such as mobile Internet, cloud computing, big data or Internet of Things with other industries to promote development of China.

The internet plus is not only related to business, but can combine with education. The internet plus education is the development of virtual learning methods which originated in 1728 Boston, while with the development of information technology, the internet plus technology is related to education and becomes to the main method in the twenty-first century. The term of internet plus education is similar to e-learning abroad and the New Zealand Ministry of Education (2004) defined the e-learning as high technology method which uses internet technology interacting with the teachers and the learners. So the internet education refers to education assisted by modern information technologies, such as internet technology and multimedia technology. The new mode of autonomous learning connects learners with teachers, and learners with educational institutions, which brings new ways of communication in autonomous learning process (Wang Lei\& Zhou Yi, 2015: 3-4, 19-20).

There is another definition, which is put forward by Shen Lijun (2018), that the internet plus education is a new form of education that uses cloud computing, learning analysis, Internet, artificial intelligence, network security and other new technologies to cross the boundaries of schools and classes and provide individual learner with high quality, flexible and personalized education and it is a deep integration of the Internet, mobile Internet and education. Moreover it is a strategic and overall educational reform that promotes educational progress efficiency and organizational change, and enhances educational innovation and productivity.

In this research, the internet plus education is particularly about the application of internet plus technology which uses the technology to break through the limitations of time and space, providing individual learners with resource-rich learning materials, and linking teachers and students to achieve efficient information exchange. Besides it can feed back information to the user in time.

All above definitions expose some characteristics of the internet plus education, which can be summarized as the following:

a. Education plus technology. It is mainly reflected in the diversity of educational methods and channels. The "plus" here is not simply adding, but deeply relate these two things to form a new type of learning relationship. This new type of learning relationship brings endless potential to learners.

b. Improving development. Due to the nature of the Internet plus, this education has more vitality to develop and innovate. So there will be more and more new methods to achieve internet plus education in the development process.

c. Optimization of the relationship. The relationship here refers to all relevant relationships, such as teaching between learning, and resource sharers between beneficiaries. Each party does not exist alone, and the two sides interact to promote 
learning together.

d. Boundlessness. Education based on Internet technology breaks the boundaries between time and space, making education resources global, and everyone who has access to the Internet can get resources for education. (Qin Hong\& Zhang Wusheng, 2016)

e. Personalization. Big data and automated system of teaching make personalized teaching possible. In the internet plus era, learners could choose what they want and like online, and the internet will recommend the appropriate method for learners.(He Xianhua, 2017)

f. Evaluation method improvement. In the internet plus education, the evaluation does not only occur at the end of the period or at the end of the month, it is usually formed by formative evaluation, which occurs after each lesson. Besides, the content of the evaluation is more comprehensive than the evaluation in the real classroom (Shen Lijun, 2018).

\section{Autonomous learning}

Autonomous learning, also called learner autonomy, originated in the 1980s, and it was first proposed by Henri Holec. Since then, many scholars have given its definition. Holec (1981) defined it as "the ability to take charge of one's own learning". Then Cotterall (1999) gives the definition that autonomous learning is the self-control process to achieve the learning goals with self-planning. As far as Dickinson (1993) gave a specific and in-depth definition of autonomous learning. He believes that autonomous learning is a process by which learners complete their own learning tasks. In the learning process, students first determine learning goals for themselves, then monitor, regulate, and control the cognition and guidance of goals. In this thesis, autonomous learning refers to learners' learning activities according to their own needs and teachers' requirements aiming to complete learning tasks, enrich learners' knowledge, and improve learners' own abilities. Moreover, it is a process in which the learner self-plans and self-supervises and its effectiveness is influenced by the learner's behavior.

Based on the above definition and self-management learning theory which is similar to autonomous learning and it mainly emphasizes the main role of learners in the learning process autonomous learning's characteristics are summarized as following:

a. Self-awareness. It emphasizes that learners have their own understanding and ideas for autonomous learning. It is mainly embodied in self-learning activities and completing learning tasks. It also shows that learners effectively avoid interference factors for efficient learning.

b. Self-regulation. It means that the learner has a purpose in the learning process and is capable of perfecting or terminating the learning plan. It ensures the efficiency of learning to a certain extent, and also reflects the self-discipline ability of learners.

c. Self-management resources. The diversity of learning resources leads learners to choose the resources that suit them. This requires learners to gain learning resources and complete their own learning tasks through extensive searching. Self-learning is a very efficient process because learners themselves understand learning plans and tasks.

d. Relatively independent. On the one side, it shows that autonomous learning is not completely independent, but can be completed under the guidance of a teacher or in collaboration with classmates. Besides it is mainly reflected in the learner-centered in the learning process, and teachers and other learners can also participate. Individuals promote each other to better complete learning tasks. On the other side, it also requires learners to choose learning strategies, methods, resources, etc. as independently as possible. (Huang Rui-Ting, 2014)

e. Dynamic evaluation. It is mainly refers to formative evaluation model, which can detect errors and deficiencies, feedback, and correct promptly. This kind of evaluation makes 
students learn better, and can also help students monitor the learning process in order to adjust the study plan. (Ren Chunmei, 2010)

In order to regard to the main models of autonomous learning, this thesis divides autonomous learning into the following four models from three aspects of metacognition, motivation and behavior with reference to the main viewpoint of Zimmerman (2002).

a. Completely independent autonomous learning. This model of autonomous learning is a completely independent learning process, including setting goals, planning, monitoring the learning process, evaluating learning outcomes, reflecting and adjusting learning plans, etc. This model has high requirements for learners' motivation and learning ability.

b. Autonomous learning under the guidance. This model mainly requires teachers or experts to guide learners' learning. The learners are relative independence.

c. Autonomous learning with mutual cooperation. This model requires the participation of peers, and learners promote each other and learn together.

d. Cooperative autonomous learning under the guidance. This model is also called inquirybased autonomous learning, which is a combination of second and third modes. (Zimmerman, 2002)

This research focuses on the second autonomous learning model. Students conduct their autonomous learning on the appointed mobile apps and the internet platforms with teachers' guidance.

\section{Autonomous learning in the Internet plus era}

Autonomous learning in the internet plus era has its own features. Jin Ruixia (2017) defines as combining internet plus technology, internet of Thing, artificial intelligence, cloud computing, Big Data and other information technologies with education, the new mode of autonomous learning considers the individual needs of the learners to provide learning information, making the learners instruct, supervise, regulate and evaluate the learning process, and establish learning system for learners' autonomous learning.

Based on the above two main concepts--- internet plus education and autonomous learning, and the viewpoint of Jin Ruixia (2017), now define it as a new mode of autonomous learning, which uses the internet plus technology to access to more resource; has high efficiency processing of information, convenient communication between learners and teachers, more flexible criteria to evaluate learners comprehensively, flexible class time and "classroom". This method of learning is very common method to get knowledge improving oneself.

Autonomous learning in the internet plus era is a product of the trend of the times and has its own significance. Teaching and learning are two parts that are inseparable. The purpose of education is to promote development of men. Autonomous learning reflects the subjective initiative of students and is the first and important step of men developing (Ma Yunpeng, 2016). The study of He Xianhua (2017) mentions this way of learning is an active and independent learning mode. It transforms the center of learning and maximizes the learner's subjective initiative. Learners become the center of learning to stimulate learners' motivation and learning potential, which greatly improves the quality of education.

More importantly, it communicates the world, and makes the resource presentation mode more and more diverse. As Barbara Schmenk (2005) proposes that the development of autonomous learning has promoted the development of information technology. On the contrary, the development of information technology has also driven the development of 
autonomous learning. The two things are mutually reinforcing and transforming the learning process. This shows the important role of autonomous learning based on Internet plus in promoting educational innovation. At the same time, this method of learning provides possibilities for equal educational opportunities.

\section{Research questions}

\section{METHODOLOGY}

This thesis aims to find out the current situation of English autonomous learning in the internet plus era and the correlation between English scores and abilities of autonomous learning with the internet plus technology. According to the aims, the following three questions are raised:

a. What is the current status of freshmen's English autonomous learning in the internet plus era?

b. Is college freshmen's autonomous learning ability correlated with their English academic achievements in the internet plus era?

c. How to improve college freshmen's autonomous learning efficiency in "the Internet Plus" era?

\section{Participants}

460 non-English major freshmen at Beijing Institute of Petro-chemical Technology (BIPT) are involved in this research as participants. They are all students with an English proficiency of level B (the intermediate level based on the Entrance Level Test hosted by BIPT). Of the freshmen, 235 are female (51\%) and 225 are male (49\%). The details of the participant information showed in the following Figure 3.1. 460 questionnaires were collected and 421 questionnaires are valid. In these questionnaires, 207 were submitted by a male freshmen (49\%), and 214 were submitted by female (51\%). Of the freshmen, 80 have three platforms and below three (19\%), 99 have four (24\%), 77 have five (18\%), and 165 have six and above (39\%). The information is contained in Figure 3.2 and Table 3.1.

Figure 3.1

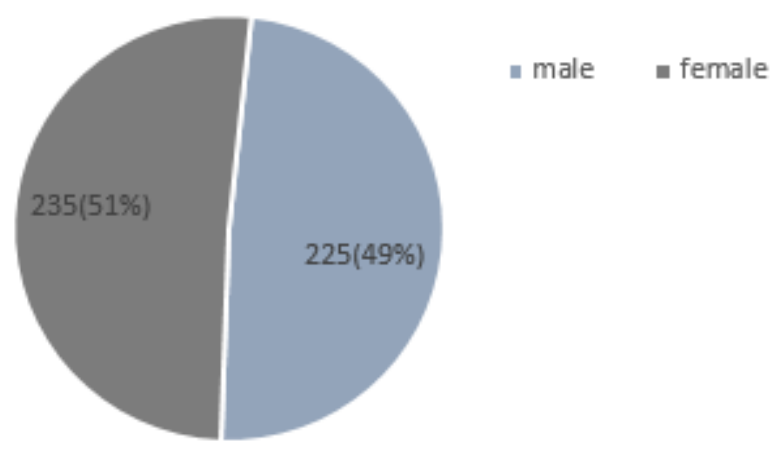

Table 3.1 Gender information of the valid questionnaires (Q1)

\begin{tabular}{|c|c|c|}
\hline Gander & Frequency & Present (\%) \\
\hline Male & 207 & 49 \\
\hline Female & 214 & 51 \\
\hline Total & 421 & 100 \\
\hline
\end{tabular}


Figure 3.2 The amount of used internet plus platforms (Q3)

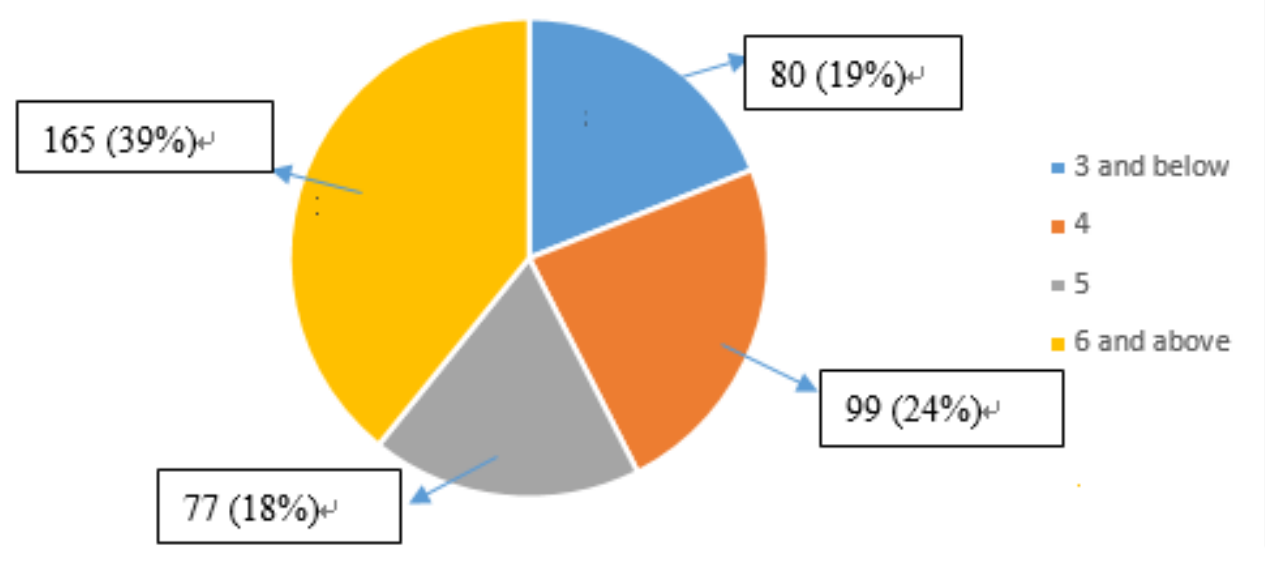

The author randomly selected three freshmen from the participants who participated in the questionnaire and conducted an eight-minute interview on the five supplementary questions. of the three freshmen, two are male students, and one is female.

\section{Instruments}

The questionnaire, with reference to Huang Rui-Ting's (2014) questionnaire, He Xianhua's (2017) and Shen Lijun's (2018), is designed to learn about the current situation of freshmen autonomous learning in the internet plus era, and the ways to improve the effectiveness of freshman autonomous learning. The questionnaire has 29 questions, consisting of personal information and questions concerning the status, difficulties and strategies of freshmen autonomous learning. The first two parts is investigated from the following four aspects: learning motivation, resource acquisition, information processing and output, while the third one is form three aspects: learning motivation, resource acquisition, and information processing. Two basic information questions, the rest are multiple-choice questions, 19 of which are five-point Likert-type scale--- completely agree (5), agree (4), not sure (3), don't agree (2) and completely disagree (1).

With internet technology, the author distributed questionnaires to about 660 freshmen in the BIPT, and 421 valid questionnaires collected, the valid rate is $91.5 \%$.

The interview, a supplementary verification of the correlation, based on the analysis of the questionnaire data. It includes five questions, which focus on the composition of the final exam paper, the content of English autonomous learning in internet plus era, the burden of academic work, and the perception of English autonomous learning. The questions of the interview are in the following:

a. Do you think the Internet plus technology has a positive effect on English autonomous learning? Why?

b. As far as the final exam is concerned, what do you think you can do to improve your grades?

c. Does the internet plus technology help you with your English learning?

d. Is English autonomous learning biased towards the classroom in the Internet plus environment, or is it biased towards self-improvement?

e. Do you think that the level of English autonomous learning proficiency can be expressed in the final exam paper? Why or not? 


\section{Procedures}

In the week before the end of the second semester in 2018, the questionnaire was prepared. With the help of teachers, the researcher conducted the questionnaire to the non-English major freshmen at BIPT. After three weeks, the questionnaire was gradually collected and the original data was downloaded from the Wenjuanxing platform. According to the completeness of the student number and the length of completion time, the invalid questionnaire was eliminated, and finally 440 valid questionnaires were obtained as the original data for subsequent data analysis. The questionnaires were divided into five parts--- usage of internet plus platforms, information acquisition and processing, problems and problems solving, and achievement, and then generated the figures and tables in order to facilitate subsequent analysis. In the first week of the first semester in 2019, the final English scores of the freshman in the last semester were also counted. The author matched the student number, 421 questionnaires were obtained for analysis the correlation between the ability of autonomous English learning and English academic scores. The proportion of the valid questionnaire is $91.5 \%$. The author used SPSS 20 to analyze the two, getting the conclusion in the following parts.

\section{FINDINGS AND DISCUSSION}

\section{The general situation of freshmen autonomous English learning in the Internet plus era}

In the era of Internet plus, the Internet plus platforms can provide a large variety of resources to facilitate freshmen's English learning. This thesis explains the first research question from the following four aspects.

\section{Usage of the internet plus technology}

Thanks to the prevailing of mobile network, the internet plus technology, including both mobile learning apps and on-line learning platforms, such as Lanmoyun APP, Fif APP, and MOOC, constitutes the major source autonomous learning. The frequency of using internet plus platforms in English learning among the freshmen is not satisfying. According to Figure 4.1, $49 \%$ of the participant's using frequency of the internet plus platforms is in the middle, and only $15 \%$ claim that they use those platforms most frequently. According to the questionnaire, the freshmen focus on their own English capabilities in the process of autonomous learning, and only $1.4 \%$ freshmen use those internet plus platforms to other aspects, such as for entertainment and relaxation. 20.5\% freshmen use those technologies in their interest areas. The details are displayed in the following Table 4.1. It is found freshmen in the era of Internet plus has a psychological bias towards English autonomous learning. According to the following Table 4.2, in the four specific aspects of English abilities--- listening, speaking, reading and writing, $31.2 \%$ of the freshmen use the Internet plus technology to practice their listening ability, which means that freshmen pay more attention to input. $27.1 \%$ of the freshmen practice their reading ability with internet plus technology. There are inputs and outputs during the reading process. With the Internet plus technology, freshmen pay little attention to their writing ability. Internet plus platforms have rich resources, but most of them are input resources, which most of this input-type knowledge requires only mechanical memory, and a few need to understand and memory. This learning process is like a stand-alone game, it is easy to get started. When output is needed, learners have to make more effort. Freshmen will choose to downplay this process. It is not enough to improve the English ability relying solely on the Internet plus technology. 
Figure 4.1 The frequency of using the internet plus platforms in English autonomus learning

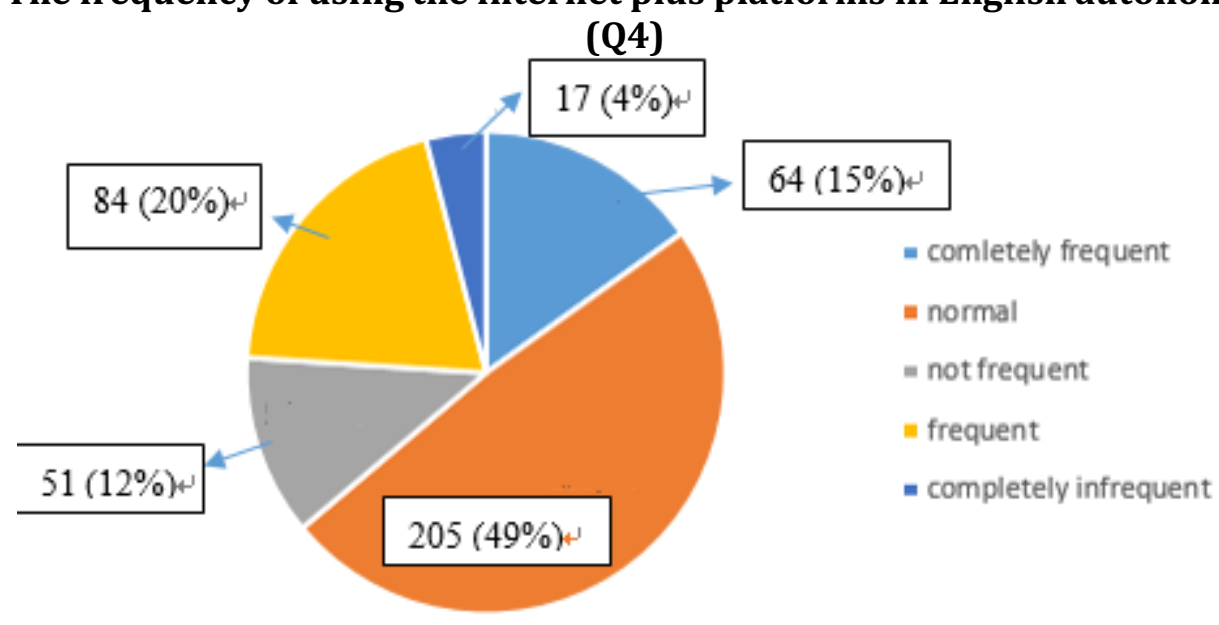

Table 4.1 The purpose of using the "Internet plus" resources

\begin{tabular}{|c|c|c|c|c|}
\hline & \multicolumn{2}{|c|}{ Responses } & \multirow[b]{2}{*}{ Percent of Cases } \\
\hline & & $\mathrm{N}$ & Percent & \\
\hline \multicolumn{2}{|c|}{$\begin{array}{l}\text { Q5: I generally use A (cooperate with the teacher's } \\
\text { these internet plusteaching tasks) }\end{array}$} & 366 & $38.6 \%$ & $86.9 \%$ \\
\hline \multirow[t]{4}{*}{ platforms to } & B (train self-English ability) & 248 & $26.2 \%$ & $58.9 \%$ \\
\hline & $\begin{array}{l}\text { C (reinforce the part that } \\
\text { interests of mine) }\end{array}$ & 194 & $20.5 \%$ & $46.1 \%$ \\
\hline & $\begin{array}{l}\mathrm{D} \text { (conduct English proficiency } \\
\text { training to get the } \\
\text { corresponding certificate) }\end{array}$ & 126 & $13.3 \%$ & $29.9 \%$ \\
\hline & E (do others) & 13 & $1.4 \%$ & $3.1 \%$ \\
\hline \multicolumn{2}{|c|}{ Total } & 947 & $100.0 \%$ & $224.9 \%$ \\
\hline
\end{tabular}

Table 4.2 The skills covered by the "Internet plus" resources

\begin{tabular}{|c|c|c|c|c|}
\hline & \multicolumn{2}{|c|}{ Responses } & \multirow[b]{2}{*}{ Percent of Cases } \\
\hline & & $\mathrm{N}$ & Percent & \\
\hline \multirow{5}{*}{$\begin{array}{l}\text { Q6:Train myself } \\
\text { with these internet } \\
\text { plus resources in }\end{array}$} & A(listening) & 324 & $31.2 \%$ & $77.0 \%$ \\
\hline & $B$ (reading) & 281 & $27.1 \%$ & $66.7 \%$ \\
\hline & C(oral English) & 247 & $23.8 \%$ & $58.7 \%$ \\
\hline & D(writing) & 157 & $15.1 \%$ & $37.3 \%$ \\
\hline & E(others) & 28 & $2.7 \%$ & $6.7 \%$ \\
\hline \multicolumn{2}{|c|}{ Total } & 1037 & $100.0 \%$ & $246.3 \%$ \\
\hline
\end{tabular}

\section{Information acquisition and processing}

In the process of autonomous learning, the acquisition and analysis of learning resources is an indispensable part. Learners' processing of information is the most important part of learning. From the questionnaire, it is found that the way of learners obtain English learning information is mainly teachers and the Internet. Only 3\% choose to get learning information from the library, and $0.4 \%$ from others. Up to $81.7 \%$ of the freshmen think that the internet can provide them the needed information for their English autonomous learning. The details are in the following Table 4.4. Also, $72.4 \%$ of the freshmen think they can clearly identify the information on the Internet and obtain effective information to help their English autonomous learning. The details are in the following Table 4.5. According to the analysis of the questionnaire date, 
most of the freshmen are very familiar with the Internet plus technology, and can skillfully use these technologies for English autonomous learning.

Table 4.3 The source of information acquisition

\begin{tabular}{|l|l|c|c|c|}
\hline \multirow{2}{*}{} & \multicolumn{2}{|c|}{ Responses } & \multirow{2}{*}{} \\
\cline { 3 - 4 } & & $\mathrm{N}$ & Percent & Percent of Cases \\
\hline \multirow{3}{*}{$\begin{array}{l}\text { Q8: Main source of } \\
\text { learning information } \\
\text { comes form }\end{array}$} & A(teachers) & 369 & $47.7 \%$ & $87.6 \%$ \\
\cline { 2 - 4 } & B(internet) & 239 & $30.9 \%$ & $56.8 \%$ \\
\cline { 2 - 4 } & C(classmates) & 139 & $18.0 \%$ & $33.0 \%$ \\
\cline { 2 - 4 } & D(library) & 23 & $3.0 \%$ & $5.5 \%$ \\
\cline { 2 - 4 } & E(others) & 3 & $0.4 \%$ & $0.7 \%$ \\
\hline \multirow{2}{*}{ Total } & 773 & $100.0 \%$ & $183.6 \%$ \\
\hline
\end{tabular}

Table 4.4 "Internet plus" technology can provide me with the information I need for effective English autonomous learning (Q14)

\begin{tabular}{|c|c|c|c|c|c|}
\hline & & Frequency & Percent & $\begin{array}{c}\text { Valid } \\
\text { Percent }\end{array}$ & $\begin{array}{c}\text { Cumulative } \\
\text { Percent }\end{array}$ \\
\hline \multirow[t]{6}{*}{ Valid } & $\begin{array}{l}\text { Completely } \\
\text { agree }\end{array}$ & 136 & 32.3 & 32.3 & 32.3 \\
\hline & Agree & 208 & 49.4 & 49.4 & 81.7 \\
\hline & Not sure & 64 & 15.2 & 15.2 & 96.9 \\
\hline & Don't agree & 10 & 2.4 & 2.4 & 99.3 \\
\hline & $\begin{array}{l}\text { Completely } \\
\text { disagree }\end{array}$ & 3 & .7 & .7 & 100.0 \\
\hline & Total & 421 & 100.0 & 100.0 & \\
\hline
\end{tabular}

Table 4.5 I can clearly identify the information on the Internet and get valid information.(Q15)

\begin{tabular}{|c|c|c|c|c|c|}
\hline & & Frequency & Percent & $\begin{array}{c}\text { Valid } \\
\text { Percent }\end{array}$ & $\begin{array}{c}\text { Cumulative } \\
\text { Percent }\end{array}$ \\
\hline \multirow[t]{6}{*}{ Valid } & $\begin{array}{l}\text { Completely } \\
\text { agree }\end{array}$ & 125 & 29.7 & 29.7 & 29.7 \\
\hline & Agree & 180 & 42.8 & 42.8 & 72.4 \\
\hline & Not sure & 94 & 22.3 & 22.3 & 94.8 \\
\hline & Don't agree & 19 & 4.5 & 4.5 & 99.3 \\
\hline & \begin{tabular}{|l|} 
Completely \\
disagree
\end{tabular} & 3 & .7 & .7 & 100.0 \\
\hline & Total & 421 & 100.0 & 100.0 & \\
\hline
\end{tabular}

\section{Problems and problems solving}

Problems in the process of English autonomous learning emerged. The author analyzed the reasons of the problems appearing, and it is easy to find that there have difficulties in the ways of problems solving of English autonomous learning. Different solutions affect learners' the next plans of autonomous learning. According to the data analysis, the author found that six factors---internal motivation, internal ability, learning aims, patience and attention affect freshmen English autonomous learning. It is worth noting that the feedback factor is not the main reason that the freshmen think affects English autonomous learning. 3\% of the freshmen have others obstructions in their process of autonomous learning, and they mention having not enough time and having no interests of English autonomous learning. The details are in the following Table 4.6. In this data, the perception of problems of freshmen is different. 55.1\% of the freshmen are not sure that the process of English autonomous learning affect by their inner 
capabilities or outside world, and $22.1 \%$ of the freshmen cannot find problems and solve immediately. At the same time, $22.8 \%$ of the freshmen can find and solve the problems appeared in their autonomous learning. The details are in the following Table 4.7. The ways of problems solving are different, and in the questionnaire, the author chose three aspects---selfregulation, internet plus technology and teachers, as research material, finding that these three aspects are divided into three questions of the questionnaire, and the freshmen think they can solve the problems by one of the three aspects, obviously showing insecurities on selfregulation aspect. The details are in the following Table 4.8, Table 4.9 and Table 4.10.

According to data analysis, the main cause of problems is not feedback. But from problems solving situation analysis, the author finds that the freshmen could not monitor their English autonomous learning. When freshmen find the problems, and solve the problems, they do not realize that they are in the main role of the learning process. They will wait for guidance of teachers or others. This is why the feedback factor is not taken seriously in the problems appearing data. In other words, in the process of English autonomous learning in the internet pus era, freshmen do not pay enough attention to the impact of their internal role on the learning process.

Table 4.6 The main reasons of problems appearing

\begin{tabular}{|c|c|c|c|c|}
\hline \multirow{2}{*}{\multicolumn{2}{|c|}{ Frequencies }} & \multicolumn{2}{|c|}{ Responses } & \multirow[t]{2}{*}{$\begin{array}{c}\text { Percent of } \\
\text { Cases }\end{array}$} \\
\hline & & $\mathrm{N}$ & Percent & \\
\hline \multirow{9}{*}{$\begin{array}{l}\text { Q26:In the Internet plus } \\
\text { environment, the main } \\
\text { reasons why I can't } \\
\text { effectively learn English } \\
\text { autonomously are }\end{array}$} & A(Insufficient internal motivation) & 219 & $20.6 \%$ & $52.0 \%$ \\
\hline & B(Insufficient self-ability) & 152 & $14.3 \%$ & $36.1 \%$ \\
\hline & C(Unclear purpose) & 133 & $12.5 \%$ & $31.6 \%$ \\
\hline & $\begin{array}{l}\text { D(Plan failure (including } \\
\text { development, implementation, } \\
\text { improvement)) }\end{array}$ & 123 & $11.6 \%$ & $29.2 \%$ \\
\hline & E(Not enough feedback) & 76 & $7.2 \%$ & $18.1 \%$ \\
\hline & F(Not enough information) & 26 & $2.5 \%$ & $6.2 \%$ \\
\hline & G(Not enough patience) & 179 & $16.9 \%$ & $42.5 \%$ \\
\hline & $\mathrm{H}($ Attention is easy to distract) & 150 & $14.1 \%$ & $35.6 \%$ \\
\hline & I(Others) & 3 & $0.3 \%$ & $0.7 \%$ \\
\hline & Total & 1061 & $100.0 \%$ & $252.0 \%$ \\
\hline
\end{tabular}

a. Dichotomy group tabulated at value 1 . 
Table 4.7 Awareness of problems in the process of independent learning (Q28)

\begin{tabular}{|l|l|c|c|c|c|}
\hline \multicolumn{2}{|c|}{} & Frequency & Percent & Valid Percent & Cumulative Percent \\
\hline Valid & Completely agree & 40 & 9.5 & 9.5 & 9.5 \\
\cline { 2 - 6 } & Agree & 56 & 13.3 & 13.3 & 22.8 \\
\cline { 2 - 6 } & Not sure & 232 & 55.1 & 55.1 & 77.9 \\
\cline { 2 - 6 } & Don't agree & 89 & 21.1 & 21.1 & 99.0 \\
\cline { 2 - 6 } & $\begin{array}{l}\text { Completely } \\
\text { disagree }\end{array}$ & 4 & 1.0 & 1.0 & 100.0 \\
\cline { 2 - 6 } & Total & 421 & 100.0 & 100.0 & \\
\hline
\end{tabular}

Table 4.8 Problem solving activity conducted alone (Q27)

\begin{tabular}{|l|l|c|c|c|c|}
\hline \multicolumn{2}{|c|}{} & Frequency & Percent & Valid Percent & Cumulative Percent \\
\hline \multirow{3}{*}{ Valid } & Completely agree & 79 & 18.8 & 18.8 & 18.8 \\
\cline { 2 - 6 } & Agree & 165 & 39.2 & 39.2 & 58.0 \\
\cline { 2 - 6 } & Not sure & 149 & 35.4 & 35.4 & 93.3 \\
\cline { 2 - 6 } & Don't agree & 21 & 5.0 & 5.0 & 98.3 \\
\cline { 2 - 6 } & $\begin{array}{l}\text { Completely } \\
\text { disagree }\end{array}$ & 7 & 1.7 & 1.7 & 100.0 \\
\cline { 2 - 6 } & Total & 421 & 100.0 & 100.0 & \\
\hline
\end{tabular}

Table 4.9 Problem solving activity conducted with the help of "Internet plus" technology (Q30)

\begin{tabular}{|l|l|c|c|c|c|}
\hline \multicolumn{2}{|c|}{} & Frequency & Percent & Valid Percent & Cumulative Percent \\
\hline \multirow{4}{*}{ Valid } & Completely agree & 172 & 40.9 & 40.9 & 40.9 \\
\cline { 2 - 6 } & Agree & 174 & 41.3 & 41.3 & 82.2 \\
\cline { 2 - 6 } & Not sure & 67 & 15.9 & 15.9 & 98.1 \\
\cline { 2 - 6 } & Don't agree & 4 & 1.0 & 1.0 & 99.0 \\
\cline { 2 - 6 } & $\begin{array}{l}\text { Completely } \\
\text { disagree }\end{array}$ & 4 & 1.0 & 1.0 & 100.0 \\
\hline & Total & 421 & 100.0 & 100.0 & \\
\hline
\end{tabular}

Table 4.10 Problem solving activity conducted with the help of teachers (Q9)

\begin{tabular}{|l|l|c|c|c|c|}
\hline \multicolumn{1}{|c|}{} & Frequency & Percent & Valid Percent & Cumulative Percent \\
\hline \multirow{6}{*}{ Valid } & Completely agree & 208 & 49.4 & 49.4 & 49.4 \\
\cline { 2 - 6 } & Agree & 158 & 37.5 & 37.5 & 86.9 \\
\cline { 2 - 6 } & Not sure & 50 & 11.9 & 11.9 & 98.8 \\
\cline { 2 - 6 } & Don't agree & 4 & 1.0 & 1.0 & 99.8 \\
\cline { 2 - 6 } & $\begin{array}{l}\text { Completely } \\
\text { disagree }\end{array}$ & 1 & .2 & .2 & 100.0 \\
\cline { 2 - 6 } & Total & 421 & 100.0 & 100.0 & \\
\hline
\end{tabular}

\section{Achievement}

Based on the above analysis, the effect of English autonomous learning in the Internet plus environment is explained from two perspectives: problem-solving ability and knowledge ability. In the Table 4.11 and Table 4.12, English knowledge competence is the main aspect that the most improvement part in English autonomous learning in the internet plus era, specifically, listening ability. $1.2 \%$ of the freshmen think that they have others aspects improvement in the process of autonomous learning, and grammar improvement is mentioned. In other abilities, time management and logical ability have been mentioned 
frequently, and $0.9 \%$ of the freshmen have mentioned other aspect, mainly in knowledge abilities.

This paper uses the final grades of the first semester of 2018 as the analysis data. Through the analysis of the questionnaire, it is found that the freshmen who are in the environment of the Internet plus have not completed well the assignment of teachers is in the largest number, and the freshmen who could not prepare well for final exam are in the largest number. The details are following in the Table 4.13 and Table 4.14 .

In the process of English autonomous learning in the internet plus era, freshmen focus on knowledge ability. Compared with knowledge acquisition, other abilities are more of an additional ability. The biggest difference between the university and the previous study period is that there is more time for self-ownership. It is necessary for the freshmen to learn learning. In the environment of the Internet plus, the improvement of the knowledge ability will lose more learning abilities. When this situation continues, freshmen cannot finish the teachers' tasks, and will lose confidence in the preparation of exams. This is mainly because freshmen cannot set up their own goals, or make relevant plans.

Table 4.11 The abilities improvement in autonomous learning at "Internet plus" era

\begin{tabular}{|c|c|c|c|c|}
\hline \multirow{2}{*}{\multicolumn{2}{|c|}{ Frequencies }} & \multicolumn{2}{|c|}{ Responses } & \multirow[b]{2}{*}{ Percent of Cases } \\
\hline & & $\mathrm{N}$ & Percent & \\
\hline \multirow{6}{*}{$\begin{array}{l}\text { Q25: In the Internet+ } \\
\text { environment, English } \\
\text { autonomous learning } \\
\text { has greatly improved me } \\
\text { in }\end{array}$} & $\begin{array}{l}\text { A(English knowledge } \\
\text { competence) }\end{array}$ & 345 & $40.6 \%$ & $81.9 \%$ \\
\hline & $\mathrm{B}($ logical ability) & 170 & $20.0 \%$ & $40.4 \%$ \\
\hline & C(Self-control $)$ & 136 & $16.0 \%$ & $32.3 \%$ \\
\hline & $\mathrm{D}$ (time management ability) & 190 & $22.4 \%$ & $45.1 \%$ \\
\hline & E(others) & 8 & $0.9 \%$ & $1.9 \%$ \\
\hline & Total & 849 & $100.0 \%$ & $201.7 \%$ \\
\hline
\end{tabular}

a. Dichotomy group tabulated at value 1 . 
Table 4.12 The knowledge competence improvement in autonomous learning in the "Internet plus" era (Q16)

\begin{tabular}{|c|c|c|c|c|c|}
\hline & & Frequency & Percent & Valid Percent & Cumulative Percent \\
\hline \multirow[t]{6}{*}{ Valid } & Listening & 194 & 46.1 & 46.1 & 46.1 \\
\hline & Oral English & 85 & 20.2 & 20.2 & 66.3 \\
\hline & Writing & 39 & 9.3 & 9.3 & 75.5 \\
\hline & Reading & 98 & 23.3 & 23.3 & 98.8 \\
\hline & Others & 5 & 1.2 & 1.2 & 100.0 \\
\hline & Total & 421 & 100.0 & 100.0 & \\
\hline
\end{tabular}

Table 4.13 The completion of teachers' assignment (Q17)

\begin{tabular}{|c|c|c|c|c|c|}
\hline & & Frequency & Percent & Valid Percent & Cumulative Percent \\
\hline \multirow[t]{6}{*}{ Valid } & Completely agree & 58 & 13.8 & 13.8 & 13.8 \\
\hline & Agree & 67 & 15.9 & 15.9 & 29.7 \\
\hline & Not sure & 92 & 21.9 & 21.9 & 51.5 \\
\hline & Don't agree & 139 & 33.0 & 33.0 & 84.6 \\
\hline & $\begin{array}{l}\text { Completely } \\
\text { disagree }\end{array}$ & 65 & 15.4 & 15.4 & 100.0 \\
\hline & Total & 421 & 100.0 & 100.0 & \\
\hline
\end{tabular}

Table 4.14 The preparation of final exam(Q21)

\begin{tabular}{|l|l|c|c|c|c|}
\hline \multicolumn{2}{|c|}{} & Frequency & Percent & Valid Percent & Cumulative Percent \\
\hline \multirow{4}{*}{ Valid } & Completely agree & 68 & 16.2 & 16.2 & 16.2 \\
\cline { 2 - 6 } & Agree & 119 & 28.3 & 28.3 & 44.4 \\
\cline { 2 - 6 } & Not sure & 166 & 39.4 & 39.4 & 83.8 \\
\cline { 2 - 6 } & Don't agree & 51 & 12.1 & 12.1 & 96.0 \\
\cline { 2 - 6 } & $\begin{array}{l}\text { Completely } \\
\text { disagree }\end{array}$ & 17 & 4.0 & 4.0 & 100.0 \\
\cline { 2 - 6 } & Total & 421 & 100.0 & 100.0 & \\
\hline
\end{tabular}

\section{Correlation between the ability of autonomous English learning and English academic achievement}

The author divided the final grades into three grades--- the high grades $(20.7 \%)$, medium $(58.7 \%)$ and low $(20.6 \%)$, analyzing respectively and concluded as the following two parts.

\section{Overall correlation}

These two aspects---teacher's tasks and feedback have a great impact on freshman's English autonomous learning in the internet plus era. According to the Table 4.15 and Table 4.16, the correlation is significant. In the autonomous English learning process, the goal of learning is set up by the teachers, and the middle learning process plans are decided by freshman. Then the 
final exams test the autonomous learning effect in the semester. Analysis shows that there are correlations between the two aspects and the English scores.

Table 4.15 The teachers' tasks in English autonomous learning

\begin{tabular}{|l|l|c|c|}
\hline \multicolumn{2}{|l|}{} & $\begin{array}{c}\text { Academic } \\
\text { achievement }\end{array}$ & $\begin{array}{c}\text { Q17: In the “Internet+" } \\
\text { environment, I can finish } \\
\text { teachers' tasks. }\end{array}$ \\
\hline \multirow{4}{*}{ Academic achievement } & $\begin{array}{l}\text { Pearson } \\
\text { Correlation }\end{array}$ & 1 & $.104^{*}$ \\
\cline { 2 - 4 } & Sig. (2-tailed) & & .032 \\
\cline { 2 - 4 } & $\mathrm{N}$ & 421 & 421 \\
\hline $\begin{array}{l}\text { Q17: In the "Internet+" } \\
\text { environment, I can } \\
\text { finish teachers' tasks. }\end{array}$ & $\begin{array}{l}\text { Pearson } \\
\text { Correlation }\end{array}$ & $.104^{*}$ & 1 \\
\cline { 2 - 4 } & Sig. (2-tailed) & .032 & 421 \\
\cline { 2 - 4 } & $\mathrm{N}$ & 421 & \\
\hline
\end{tabular}

Table 4.16 The feedback in the English autonomous learning process

\begin{tabular}{|l|l|c|c|}
\hline \multicolumn{2}{|l|}{} & $\begin{array}{c}\text { Academic } \\
\text { achievement }\end{array}$ & $\begin{array}{c}\text { Q24: “Internet+" technology } \\
\text { provides good feedback and } \\
\text { helps me to make better self- } \\
\text { feedback }\end{array}$ \\
\hline \multirow{2}{*}{ Academic achievement } & $\begin{array}{l}\text { Pearson } \\
\text { Correlation }\end{array}$ & 1 & $-.130^{* *}$ \\
\cline { 2 - 4 } & Sig. (2-tailed) & & .008 \\
\cline { 2 - 4 } & $\mathrm{N}$ & 421 & 421 \\
\hline $\begin{array}{l}\text { Q24: “Internet+" } \\
\text { technology provides } \\
\text { good feedback and helps } \\
\text { me to make better self- } \\
\text { feedback }\end{array}$ & $\begin{array}{l}\text { Pearson } \\
\text { Correlation }\end{array}$ & $-.130^{* *}$ & 1 \\
\cline { 2 - 5 } & Sig. (2-tailed) & .008 & 421 \\
\hline
\end{tabular}

\section{Specific correlation}

The author analyzes the impact of the process of autonomous English learning on different levels of grades. According to Table 4.17 and Table 4.18, it is found that among freshmen who have higher scores, information processing has the greatest impact on their academic achievements, while among the freshmen who have lower grades, solving problems through the Internet has the biggest impact on their academic performance. According to data analysis, it is easy to find out that freshmen with high scores have relatively high autonomous learning ability. They are sensitive to the aspect of information processing in the English autonomous learning, while freshmen with lower scores pay attention to the process of solving problems based on the internet plus technology, and they obviously lack the autonomous learning abilities. Many problems arise in the autonomous learning process because of the lack of these abilities, so they need to spend more energy on problems solving process. According to the analysis, these problems are mainly based on Internet technology, which indicates that they are not skilled in the application of Internet technology in their autonomous learning process. 
Table 4.17 The Information processing in the high scores

\begin{tabular}{|c|c|c|c|}
\hline & & $\begin{array}{c}\text { Academic } \\
\text { achievement }\end{array}$ & $\begin{array}{c}\text { Q15: I can clearly } \\
\text { identify the information } \\
\text { on the Internet and get } \\
\text { valid information. } \\
\end{array}$ \\
\hline \multirow{3}{*}{ Academic achievement } & $\begin{array}{l}\text { Pearson } \\
\text { Correlation }\end{array}$ & 1 & $.239^{*}$ \\
\hline & Sig. (2-tailed) & & .026 \\
\hline & $\mathrm{N}$ & 87 & 87 \\
\hline \multirow{3}{*}{$\begin{array}{l}\text { Q15: I can clearly identify } \\
\text { the information on the } \\
\text { Internet and get valid } \\
\text { information. }\end{array}$} & $\begin{array}{l}\text { Pearson } \\
\text { Correlation }\end{array}$ & $.239^{*}$ & 1 \\
\hline & Sig. (2-tailed) & .026 & \\
\hline & $\mathrm{N}$ & 87 & 87 \\
\hline
\end{tabular}

Table 4.18 The problems solving in the low scores

\begin{tabular}{|l|l|c|c|}
\hline \multicolumn{2}{|l|}{} & $\begin{array}{c}\text { Academic } \\
\text { achievement }\end{array}$ & $\begin{array}{c}\text { Q30: I think some } \\
\text { problems need to be } \\
\text { improved by “Internet+" } \\
\text { technology. }\end{array}$ \\
\hline \multirow{4}{*}{ Academic achievement } & $\begin{array}{l}\text { Pearson } \\
\text { Correlation }\end{array}$ & 1 & $-.212^{*}$ \\
\cline { 2 - 4 } & Sig. (2-tailed) & & .049 \\
\cline { 2 - 4 } & $\mathrm{N}$ & 87 & 87 \\
\hline \multirow{2}{*}{$\begin{array}{l}\text { Q30: I think some } \\
\text { problems need to be } \\
\text { improved by “Internet+" } \\
\text { technology. }\end{array}$} & $\begin{array}{l}\text { Pearson } \\
\text { Correlation }\end{array}$ & $-.212^{*}$ & 1 \\
\cline { 2 - 4 } & Sig. (2-tailed) & .049 & 87 \\
\cline { 2 - 4 } & $\mathrm{N}$ & 87 & \\
\hline
\end{tabular}

\section{Discussion of the interview}

Freshmen can get information that they needed with the help of teachers and the internet plus technology, conducting English autonomous learning in their school time for their English knowledge, learning abilities, and other fields of interest. But freshmen are obviously lacking of autonomy in English autonomous learning in the internet plus era. They have no clear goals for autonomous learning and their participation is not enough. All the interviewees said that they did not conduct English autonomous learning well when they were in school, because they focused on activities in university and had no more time and energy to make their own learning plans and conduct them successfully. One of the interviewee said, "I can't finish the tasks assigned by the teachers." And he also said that he cannot make plans based on his teacher's tasks, which causes his failure in English autonomous learning. According to the analysis of correlation, it can be found that freshmen with high scores in English tests have high abilities in autonomous learning. Based on the above analysis, it can be seen that attention and engagement of the freshmen in English autonomous learning is far from enough. Besides, freshmen are lacking of autonomous learning ability. These factors lead to the result of English autonomous learning is not unsatisfactory.

\section{Major findings}

\section{CONCLUSION}

On the whole, the general situation of freshmen's autonomous learning is not satisfying. First, although most freshmen with an English proficiency of level B have the consciousness to utilize various platforms online and apps on smart phones to conduct autonomous learning, they have 
great difficulty making a long-term learning plan or following the plan regularly. Second, a majority of freshmen have the intention to improve their English competency through autonomous learning in the "Internet-plus" environment. However, they have problems in information processing and knowledge acquisition. The personalized feedback or assessment automatically yielded online does not boost students' improvement. Finally, despite the fact that more than half of freshmen actively use platforms online and apps on smart phones, they actually lack the inner motivation for learning. In other words, and they just follow the teachers' instructions passively and heavily depend on teachers' guidance in the autonomous learning process to complete the tasks. When they have troubles, they have no motives to find the solutions on their own. Some freshmen also lack the ability of self-planning, which generates negative attitude in their learning process.

As for the correlation between freshmen's autonomous learning ability and their academic achievements, the answer is positive. Freshmen with better abilities of autonomous learning tend to get higher scores in the English test. So is the other way around. There is one thing worthy to be mentioned. Among freshmen with higher scores, their academic achievements are closely related to their ability of information processing, while for freshmen with lower scores, their academic achievements are significantly associated with their ability of problem solving. It shows that freshmen who are good at information processing tend to have better performance in the language test, compare with those who are expert in problems solving.

To improve freshmen's autonomous learning ability, the author proposes the following solutions from different perspectives: teachers, students and college administration. As teachers, they should strengthen management and feedback in the process of autonomous learning, identifying problems in time, and correcting them in time. Of course, when the task is assigned, it is necessary to make corresponding changes according to the actual situation. As students, they should be more self-disciplined in terms of self-planning and self-supervising. Develop their own abilities of solving problems is important. At the same time, in the process of autonomous learning, they'd better maintain great enthusiasm and vigor. From the viewpoint of administration, administrators should provide more technical support for freshmen, and offer courses or programs on computer technology to enable more freshmen to profit from Internet plus technology.

\section{Implication}

The autonomous learning ability plays a vital role in self-development in the "internet plus" era. The freshman year in college is much different from the previous learning stages. Freshmen who can adjust them to the new environment of learning could be outstanding learners in English autonomous learning. Of course, the results of English autonomous learning cannot be accurately measured with a final exam. In the interview, the interviewees said that the achievements of English autonomous learning are about preparing for their future, rather than the present exams. It shows that freshmen gradually pay attention to English autonomous learning, but they should further improve their ability of English autonomous learning, changing their attitude to learning, becoming more positive about their education in the "internet plus" era.

As teachers, they should guide freshmen, to a greater degree, onto the track of more productive English autonomous learning. Teachers should pay attention to training students' learning ability while instructing knowledge. They should trust their students and give them more opportunities to learn more independently and let them experience the greater autonomous learning. Positive feedback will make students become sponges that are hungry for knowledge. 
This can also enhance the freshmen's self-discipline, which will ameliorate the ways of problems solving, and increase the possibilities of learning.

\section{Limitation and suggestion for further study}

Owing to the limited time and resources, the content of the questionnaire does not cover the integral parts of English autonomous learning in the internet plus era. The quantity of the sampling is not large enough.

The author hopes that more researches would be done to further explore the nature of autonomous learning in the "Internet plus" era and make it a booster for education and selfdevelopment. The further researches can expand the scope of the subjects, which can make the data more convincing and get a more accurate conclusion in the field of English autonomous learning.

\section{References}

Barbara, S. 2005. Globalizing Learner Autonomy [J], TESOL Quarterly (1): 107-109.

Cotterall. S. (1999). Key variables in language study: What do learners believe about them? [J]. System (27): 493513.

Dickinson, L. (1993). Talking Shop: Aspects of Autonomous Study [J], ELT Journal (4): 330-335.

Holec, H. 1981. Autonomy and Foreign Language Study [M], Oxford: Pergamon Press.

Huang, R. T. (2014). Explorring the Moderating Role of Self-Management of Learning in Mobile English Leraning [J], Eduactional Technology\& Society (4), 255-267.

He, X. H. 2017. A Study on the English Autonomous Learning Situation of Senior High School Students in "the Internet Plus" Era [D]. Guilin: Guangxi Normal University.

Jin R. X. 2017. Cultivation of College Students' Autonomous Learning Ability in the "Internet Plus" Era [J], China Adult Education (22): 18-21.

Li, K.Q. 2015. China unveils targets for 2015: Li Keqiang's speech as it happened [OL]. $<$ http://www.scmp.com/news/china/article/1729846/live-li-keqiang-unveils-chinas-annual-work-report>.

Liu C.Y., Wang Y. F. 2007, Study of Freshmen's Role-changes and Goal-setting [J], China Adult Education (10): 6465.

Ma Y. P. 2016. Guarantee of Self-fulfillment Learning Freedom: All-round Development of College Students in the Internet Environment [J], Teaching Theory and Practice (27): 30-32.

Ministry of Education, 2004, Interim Tertiary E-learning Framework [OL].

<http://cms.steo.govt.nz/NR/rdonlyres/17D7A181-CD49-4D18-B84E-EE0D57149BC5/0/Interim Tertiarye

Learning Frameworkweb.pdf>.

Qin H., Zhang W. S. 2016. Features and Tendency of the Development of the "Internet-plus" Education [J], Education Research (6): 8-10.

Ren C. M. 2010. Study of the Assessing System of College Students' Autonomous Learning [J], Modern Education Science (5): 150-152, 176.

Shen L. J. 2018. The Current Situation and Development Strategy of College Students' Autonomous Learning in the "Internet Plus" Background [D], Jiangsu: Jiangnan University.

Wang L.2014. Action Research on Improving Freshmen's Learning Motivation [J], Shandong Foreign Language Teaching (5): 73-78.

Wang L., Zhou J. 2015. Boundless: Internet-plus Education [M], Beijing: Zhongxin Press

Yao M. L., Xu S. S. 2002. Self-adjustment Learning: A Jump of Self-efficacy [M], Beijing: China Light Industry Press.

Zhang S. J. 2018. Exploring College Students' Learning Motivation [J], Guangdong Sericulture (10): 104-105. 